\title{
Prazer e risco, medo e aventura, vergonha e luta por reconhecimento: \\ Uma etnografia da formação tensional do self dissidente no urbano contemporâneo Brasileiro
}

\section{Resenha do livro: OLIVEIRA, Jainara Gomes de. Prazer e Risco nas práticas homoeróticas entre mulheres. Curitiba: Appris, 2016.}

Raoni Borges Barbosa

Doutorando em Antropologia -PPGA/UFPE Pesquisador do GREM - Grupo de Pesquisa em Antropologia e Sociologia das Emoções raoniorgesb@gmail.com 
Oliveira apresenta em sua recente obra Pražer e risco nas práticas homoeróticas entre mulheres uma etnografia da formação tensional do self dissidente no urbano contemporâneo brasileiro a partir da cidade de João Pessoa, capital do Estado da Paraíba. A autora, nesse sentido, oferece ao leitor uma descrição densa (GEERTZ, 1978) dos circuitos de lazer, dos lugares de militância política e cultural e das sociabilidades íntimas e privadas de mulheres em busca de uma auto-definição e, também, de uma autoafirmação a partir de práticas homoeróticas.

A obra conjuga, ainda, uma análise crítica e reflexiva sobre o estatuto político e médico da luta por reconhecimento social que os atores sociais observados cotidianamente organizam em suas trajetórias e projetos individuais e coletivos (VELHO, 1987). Daí o compromisso de Oliveira em desenvolver e comunicar uma objetificação participante (BOURDIEU, 2002) da sua experiência de campo, discorrendo sobre os gradientes de tensão e conflito que influenciam o mundo emocional-moral e cognitivo-comportamental de mulheres reais em situações de praz̧er e risco, medo e aventura, vergonha e luta por reconbecimento.

As emoções medo e vergonha são categorias centrais na análise dos prazeres e riscos constituintes do processo de formação do self dissidente em um contexto urbano de relações individualistas. O medo do outro e a vergonha de si enquanto indivíduo relacional que desafia a visão hegemônica de sexualidade são emoções que organizam e tensionam a imagem e a fachada que a mulher com práticas homoeróticas articula para poder deslocar-se em situações de quase clandestinidade e invisibilidade.

A vergonha, nesse sentido, é discutida como uma dor social profunda e que conduz a individualidade a processos lentos de reflexão sobre o fazer-se em uma sexualidade dissidente e, portanto, moralmente classificada como abjeta e ameaçadora. Dor esta vivenciada cotidianamente por uma individualidade confrontada com experiências de constrangimentos, exclusão social e humilhação, configurando, destarte, uma carreira moral de estigma, mas, também de aventura pelo novo e de luta pelo reconhecimento, pelo autorrespeito e pela aceitação social.

Em seus percursos etnográficos pela cidade de João Pessoa, Oliveira logrou construir uma cartografia dos desejos homoeróticos, localizando, no espaço urbano, circuitos de bares, ONGs, praças, bordéis, clínicas e outros pontos conectados em uma 
rede de acomodação e de encontro de saberes e práticas dissidentes. A autora faz um recorte a partir da categoria de gênero para integrar memórias, trajetórias e projetos de mulheres de classes, idades e padrões educacionais e laborais variados.

Oliveira implode e amplia intencionalmente a noção epidemiológica de risco, tão cara à epidemiologia e à antropologia da saúde da qual é egressa, - e assume, no argumento da sua etnografia, a perspectiva, o olhar e os significados íntimos que verifica como centrais na cultura emotiva (KOURY, 2009) de sociabilidades urbanas homoeróticas. Sociabilidades estas que se organizam na marginalidade envergonhada e amedrontada do armário enquanto estratégia de evitação de constrangimentos cotidianos (GOFFMAN, 2010 e 2012); de proteção de identidades tidas como moralmente poluentes e deterioradas; de segregação de plateias e de papeis; mas, também, como organização de intimidades, compromissos, projetos e memórias pautadas na amiz̧ade, na confiança e no cuidado recíproco.

A noção de risco, portanto, para Oliveira, vai além da discussão epidemiológica de controle social mediante políticas públicas para casais sorodiscordantes e que tem como centro gravitacional o serviço médico-hospitalar, o serviço social e outras agências estatais ou para-estatais de imposição pública (GUSFIELD, 2014) de comportamentos e condutas. Para a autora, com efeito, importa analisar o risco enquanto noção íntima e nativa, real e mundana, assim como este acontece nos modos de ação e de realidade de mulheres com práticas homoeróticas.

Nas palavras de Oliveira (2016, p. 150):

As noções de risco e prazer perpassam, a título de conclusão, não apenas as percepções de risco epidemiológico relacionados às possibilidades de infecção por DST e HIV/Aids entre mulheres sorodiscordantes ou não. Bem mais abrangente, o risco entendido em seu aspecto relacional amplo também se configura como um elemento central desse processo social de construção de intimidades e compartilhamentos.

Tal implica, igualmente, perceber o risco de uma perspectiva mais relacional e simbólico-interacionista do social e da cultura, atentando para a formação tensional, ambígua, transintencional e não-linear das montagens morais, das emoções, das narrativas e discursos de justificação e desculpa de si e do outro que caracterizam o viver 
clandestinamente ou à margem as práticas homoeróticas no armário. Com efeito, a etnografia de Oliveira preocupa-se com as micro-políticas das emoções produzidas em situações de segredos de polichinelo (BOLTANSKI, 2012), de escandalização de ações tidas como moralmente ilegítimas e de consequentes rupturas de vínculos fortes.

Nas palavras de Boltanski (2012, p. 212-213):

Uma compilação de dados etnográficos permite extrair um outro traço intrigante, congruente com o par indignação-tolerância. Quando praticado, o aborto em geral é feito secretamente ou, ao menos, ao abrigo dos olhares. Porém, na maioria das vezes, é que se chama popularmente de "segredo de polichinelo". Esse tipo de figura deve atrair nossa atenção para uma oposição que exerce um papel importante em relação a nosso objeto: trata-se da oposição cuja análise foi particularmente desenvolvida na obra etnológica de Pierre Bourdieu, principalmente nos textos consagrados ao parentesco- entre o que concerne ao oficial, dotado de um caráter "público, solene, coletivo", e o que, tangendo ao oficioso, é condenado a um modo de existência "vergonhoso", até mesmo "clandestino". Essa oposição pode dizer respeito à distribuição de diferentes tipos de ação ou diferentes formas de poder.

A experiência de quebras de vínculos familiares e vicinais, tão logo situações acidentais vexatórias ou de empoderamento mínimo das mulheres são produzidas, aparecem reiteradamente nas narrativas de fazer-se mulher com práticas homoeróticas. O indivíduo que se lança publicamente em um projeto de experimentação da diferença e de construção de si enquanto self dissidente vê-se confrontado com as sanções negativas, oficiais e oficiosas, da normalidade normativa brasileira calcada nos modelos e padrões heterossexuais de expressão do desejo pelo outro e de organização do próprio corpo.

Oliveira, nesse diapasão, analisa a construção de trajetórias de mulheres que romperam total ou parcialmente com suas famílias, pequenas cidades e mundos de trabalho, de modo a poderem se afirmar como individualidades e selves dissidentes. $\mathrm{O}$ prazer das práticas homoeróticas, entendidas e sentidas tensional e intensamente como elemento instituinte da diferença do estilo de vida abordado, assim, aparece não somente como aventura e luta por reconhecimento, mas também como medo e vergonha de si e do outro.

Trata-se, em resumo, de um importante trabalho de pesquisa, agora lançado em 
formato de livro. Com sua obra, Oliveira presenteia o leitor com uma cuidadosa reflexão etnográfica sobre um modo e estilo de vida ainda envergonhado, amedrontado e constrangido nas gramáticas do armário, mas, também, em luta por visibilidade, aceitabilidade e reconhecimento social.

\section{Referências bibliográficas}

BOLTANSKI, Luc. As dimensões antropológicas do aborto. Revista Brasileira de Ciência Política, nº7, 2012, p. 205-245.

BOURDIEU, Pierre. Participant Objetification. Journal of Royal Anthropology Institute, 9 (2): 281-294, 2002.

GEERTZ, Clifford. A interpretação das culturas. Rio de Janeiro: Zahar Editores, 1978.

GOFFMAN, Erving. Comportamento em lugares públicos: Notas sobre a organização social dos ajuntamentos. Petrópolis: Vozes, 2010.

GOFFMAN, Erving. Ritual de interação: ensaios sobre o comportamento face a face. Petrópolis: Vozes, 2012.

GUSFIELD, Joseph R. La cultura de los problemas públicos: el mito del conductor alcoholizado versus la sociedad inocente. Buenos Aires: Siglo Veinteuno Editores, 2014.

KOURY, Mauro Guilherme Pinheiro. Emoções, Sociedade e Cultura: A categoria de análise Emoções como objeto de investigação na sociologia. Curitiba: Ed. CRV, 2009.

VELHO, Gilberto. Projeto, emoção e orientação em sociedades complexas. In: Gilberto Velho. Individualismo e Cultura, $2^{\text {a }}$. Edição, Rio de Janeiro: Jorge Zahar, p. 13-37, 1987. 